\title{
Manoeuvring and Hoteling External Costs: Enough for Alternative Energy Sources?
}

Authors:

Corresponding author

Marcel·la Castells Sanabra, PhD

Lecturer

Academical Secretary

Department of Nautical Sciences and Engineering Universitat Politècnica de Catalunya (UPC), BarcelonaTech mcastells@cen.upc.edu

Co authors:

Juan José Usabiaga Santamaría, PhD student Assistant Teacher

Department of Nautical Sciences and Engineering Universitat Politècnica de Catalunya (UPC), BarcelonaTech jusabiaga@cen.upc.edu

Francesc Xavier Martínez de Osés, PhD

Associate Professor

Director

Department of Nautical Sciences and Engineering Universitat Politècnica de Catalunya (UPC), BarcelonaTech fmartinez@cen.upc.edu 


\begin{abstract}
Local air pollution is the most relevant externality of maritime transport and its effects are more acute in urban areas as a result of manoeuvring, hoteling, and load/unload activities at ports. This paper is intended to assess ships' local air pollution impact in generally densely populated harbor areas, in order to decide whether or not alternative power supply measures are feasible. First, an optimized infrastructure investment model is developed to ease implementation and maximize the efficiency of alternative power supply projects. Once target harbors and traffic (ship types) within a national port network have been chosen, a vessel traffic analysis (ship type, tonnage, manoeuvring and hoteling times) is carried out to quantify and evaluate annual polluting emissions $\left(\mathrm{PM}_{2,5}, \mathrm{SO}_{2}, \mathrm{NOx}\right.$ and VOC-s) and their externalities. Finally, the assessment model is applied and results of the Spanish port network case study are discussed. The results obtained are significant and bring the possibility of further controlling the ship's environmental performance at berth.
\end{abstract}

\title{
Keywords
}

Sustainability, Ports, Regulation, Terminals, Policy 


\section{Introduction}

Ship operators often seek well located (close to industrial areas) and connected (infrastructures) ports. Often the answer to these requirements is a major port located next to a densely populated urban area. Due to the port-city closeness, local air pollutants are expected in urban areas as a result of manoeuvring, hoteling, and load/unload activities at ports. In harbour cities, maritime activity is often a dominant source of urban pollution, causing environmental problems affecting both human health and ecosystems (Miola et al. 2009). According to a European Commission study, the amount of pollution emitted by vessels during manoeuvring, loading, unloading, and hoteling phases are respectively 4,5\% of $\mathrm{SO}_{2}$ and $6,2 \%$ of $\mathrm{NOx}$ of the total emitted by ships (Gariazzo et al. 2007). Moreover for the European environmental management noise and air quality were the most relevant issues over operational activities such as port waste management, dredging, and port expansion in 2009 (ESPO 2010). Faced with this scenario, some policy instruments aimed at reducing local air pollution at ports are necessary, especially in those located close to urban areas where air pollution's impact is more acute (Schrooten et al. 2008).

This paper is intended to assess ships' local air pollution impact in generally densely populated harbour areas, in order to decide whether or not alternative power supply measures are necessary and feasible. The methodology used in this research is based in well-known projects regarding both emissions estimation and impact valuation. The results obtained are significant and bring light to further controlling ships environmental performance at berth.

The paper is structured into the following sections: section 1 introduces the problem and the existing background; section 2 discusses related research, determining the state of art and explaining the methodology to be followed; section 3 applies the developed model into the Spanish port network and corresponding traffics; section 4 presents results according to formulas reported in section 3; section 5 gathers main conclusions and findings; and finally section 6 states further research to be carried out on this topic.

\subsection{Maritime transport air pollution}

Maritime transport is well known due to its energy efficiency when compared with other means of transport. One of the most urgent environmental problems facing the shipping industry today is the reduction of Greenhouse Gas emissions (Giziakis and Christodoulou 2012). However, emissions are not only driven by energy consumption and because of using dirtier fossil fuels air pollution is maritime transport's weak point (Usabiaga 2009). This paper covers externalities produced by direct emissions to air made by ships when at port, i.e. during manoeuvring and hoteling phases. Indirect emissions produced upstream or downstream in the shipping sector (energy production, ship scrapping, etc.) are not considered, neither they are the emissions produced by auxiliary services such as towing operations. Emissions of Particulate Matter $\left(\mathrm{PM}_{2,5}\right)$, Sulphur Dioxide $\left(\mathrm{SO}_{2}\right)$, Nitrogen Oxides (NOx), and Volatile Organic Compounds 
(VOC-s) are studied. Although other pollutants are also emitted, these are considered the most relevant.

$\mathrm{PM}_{2.5}$ and $\mathrm{SO}_{2}$ emissions are relevant for local impact, as they are able to cause damage in the original form in which they are released. This impact is related to health problems and therefore dependent on the proximity between emission sources and receptors. The population density around the emissions source is critical. On the other hand NOx emissions do not produce a local impact besides a rural one, given that impacts of NOx are linked to the formation of associated secondary pollutants in the atmosphere. Therefore variation in population density around ports has little effect on externalities arising from NOx emissions (Tzannatos 2010b).

As ozone and aerosol precursors, and hence responsible of the rural impact; NOx, VOC$\mathrm{s}$ and $\mathrm{SO}_{2}$ need to be transported a certain distance (hundreds of kilometres) in the atmosphere while undergoing chemical processes before generating associated secondary pollutants (ozone, nitrate aerosols, and sulphur aerosols). These associated pollutants produce impact mainly in form of sulphur deposition (acid rain), eutrophication (excess of nitrogen nutrient) and ozone formation.

\subsection{Regulatory framework for air emissions from ships}

The international nature of maritime activity, the sector itself and the governing regulatory framework, makes it complex to design and implement policies to abate emissions to air. In 2001, the European Union expressed its concerns about transportrelated impact through the Strategy for Sustainable Development published in its White Paper on Transport Policy (EC 2001).

Current regulatory action seeks to reduce emissions from ships, forcing the introduction of new abatement technologies and establishing minimum fuel quality standards.

The main regulatory body is the International Maritime Organization (IMO), the United Nations specialized agency responsible for the safety and security of shipping and the prevention of marine pollution by ships. The International Convention for the Prevention of Pollution from Ships, MARPOL 1973/1978 (IMO 2008), is the main IMO convention aimed at preventing and minimizing pollution from ships, both accidental pollution and that resulting from routine operations.

Air pollutants emission from ships is covered by MARPOL's Annex VI, which was enforced in 2005. This annex sets limits on Sulphur Oxide and Nitrogen Oxide emissions from ship exhausts as well as Particulate Matter and prohibits deliberate emissions of ozone-depleting substances. In 2008, the IMO Marine Environment and Protection Committee (MEPC) amended Annex VI and the revised text introduced Emissions Control Areas (ECA-s) in which, due to air quality problems, more stringent emissions policies are in force since July 1, 2010.

IMO NOx emission standards are known as Tier I-III. Tier I standards were introduced by the 1997 MARPOL protocol and adopted in 2005, when air pollution was introduced into Annex VI. Tier II and III standards were introduced in 2008, when Annex VI was amended by the MEPC. Progressively restrictive policies regarding NOx emissions are being enforced (MEPC 2008). 


\begin{tabular}{|l|l|}
\hline Construction year & \multicolumn{1}{|c|}{$\begin{array}{c}\text { NOx emissions } \\
\text { limits }\end{array}$} \\
\hline Pre 1990 & None \\
\hline $1990-1999$ & Tier 0 \\
\hline $2000-2010$ & Tier I \\
\hline $2011-2015$ & Tier II \\
\hline Post-2016 & Tier III \\
\hline
\end{tabular}

Table 1.NOx emissions limits. Source: own, based on port MARPOL Annex VI, Regulation 13.

Annex VI establishes two sets of fuel quality and emissions standards: Global requirements, and more stringent requirements applicable to ships operating in ECAs.

MARPOL Annex VI seeks a progressive reduction in SOx emissions limiting the sulphur content in marine fuel oils.

Moreover, the EU is going beyond IMO emission standards, and it has established even more stringent sulphur standards with the so called Sulphur Directives: Directives 2005/33 and 1999/32 (ED 2006). These directives limit the sulphur content in marine fuels used by ships at berth in EU ports to 0,1\%, with the exceptions of ships that spend less than two hours at berth and ships which switch off all engines and use shore-side electricity when at berth. Standard enforced since January 2010: A sizeable reduction in emissions and associated external costs is achieved whether operating on ultralowsulphur fuel or on shore-side electricity (Tzannatos 2010a).

\begin{tabular}{|l|l|l|}
\hline \multicolumn{1}{|c|}{ Area } & \multicolumn{1}{|c|}{ Period } & Max. fuel sulphur content \\
\hline Port & Post January 1,2010 & $0,10 \%$ \\
\hline \multirow{2}{*}{ SECA-s } & July $1,2010-2015$ & $1 \%$ \\
& Post January 1, 2015 & $0,10 \%$ \\
\hline \multirow{3}{*}{ Global } & Pre January 1, 2012 & $4,50 \%$ \\
& January 1, 2012 -2020 & $3,50 \%$ \\
& Post January 1,2020 & $0,50 \%$ \\
\hline
\end{tabular}

Table 2. Maximum Sulphur contents of fuel. Source: own, based on port MARPOL Annex VI, Regulation 14, and EC Sulphur Directives 2005/33 and 1999/32.

\subsection{The problem}

Several harbour cities are suffering from local air quality problems and are currently looking for appropriate instruments to correct them. Appropriate instruments need comprehensive assessment and there is currently no study quantifying ship air pollution costs in Spanish harbour cities.

Moreover, measures able to correct current air quality problems, such as alternative power supply, are expensive and require significant investment. Such investments are not made if turnover and economic efficiency are not guaranteed. In this respect, extensive implementation for all ships and harbours is not economically effective; therefore, an optimized implementation model is required.

\subsection{Objectives}

The objectives of this paper, in chronological order, are: 
- Identify target harbours and vessel traffics maximizing the feasibility and optimizing the implementation of alternative power supply means.

- Define a methodology to quantify the amount of emissions to air, during port phases, from ships and their impact in harbour cities.

- Discuss the Spanish port network case study.

- Determine an efficient alternative power supply network within a national port system.

- Demonstrate the need to introduce more stringent maritime policies aimed at reducing emissions to air from ships at port.

\section{Methodology}

\subsection{Port traffic assessment}

The first task involves ship type targeting and port identification. Ship types commonly engaged in regular traffic are: Ro-Ro, passenger, and container ships (UNCTD 2010). Regular traffics are targeted as are identified as these maximize the investment return by high infrastructure utilization rates. Moreover passenger, Ro-Ro and container ships are among ship types presenting higher energy consumptions when at berth.

Therefore regular traffic shares are calculated for each port, attending to the number of Ro-Ro, passenger and container ship calls at port. Once regular traffic shares are known, target ports are identified, choosing those with a significant regular traffic share (above $50 \%$ of the total traffic).

When it comes to air pollutants emission, existing estimation methodologies consider three different navigation phases: at sea, manoeuvring, and hoteling phases. Nevertheless, only the manoeuvring stage (arrival and departure) and the hoteling stage (while moored) are relevant for harbour emissions estimation. In this respect, assumptions done by ENTEC 2002 (Whall et al. 2002) are used. These assumptions are described in section 3 .

\subsection{Emissions estimation and impact valuation}

Once target ports, traffics, manoeuvring times and hoteling times are known, ships environmental performance regarding air pollutants emission when at port is assessed. The impact assessment of emissions to air from maritime transport needs a twodimension analysis. Both quantity of emitted pollutants (mass) and the emission site (sensitivity) must be considered for impact valuation purposes.

\subsubsection{Emissions estimation}

Existing literature and authors' studies estimate ship emissions following two different methodologies: fleet activity-based emissions estimation methodology or fuel salesbased estimation methodology. The latter is used for macro analysis, global scope, in which precise data about traffics to be analysed (ship type, engine type, ship size, engine power, etc.) is not available. Few are the studies using fuel sales as source data for emissions estimation being one of the most recent by Endresen et al. (2007). However fleet activity based studies are numerous, and authors usually prefer this methodology as its accuracy is believed to be higher if provided with correct 
assumptions regarding parameters such as ship type, ship size and engine type among others. Studies published by Wang et al. (2007), Schrooten et al. (2008), Paxian et al. (2010) and ENTEC (2010) are some examples.

Due to the limited geographical extent of this work, the fleet activity methodology is chosen as suggested by Winther (2008). This methodology uses detailed ship types and traffic data together with emission factors in order to obtain estimates.

In addition, a top-down approach is chosen for ship type and traffic data analysis. As different ship types have different characteristics (GT and engine type), disaggregation is needed and port calls are split into three groups formed by the selected ship target groups (Ro-Ro, passenger, and container ships). Port calls in each of these three groups are considered as a single activity with same characteristics (mean GT, mean engine power, mean auxiliary engine power, manoeuvring and hoteling times, and emissions factors).

The methodology quoted as Tier III in the EMEP/EEA air pollutant emission inventory guidebook 2009 is used for the estimation of air polluting emissions from ships.

This methodology requires detailed ship movement data besides technical information on ships. Further focusing on the emissions estimation methodology demonstrates that this work follows the procedure using data on installed main and auxiliary engine power, load factor and total time spent on each navigation phase. The Tier III method also employs specific emission factors for different engine types and fuel combinations, as well as for navigation phases (table 7 and 8 ).

\subsubsection{Impact valuation}

The majority of air pollution externalities are site specific. That is, they are produced at a local scale just after the pollutants (PM and SOx primarily) have been released. In order to achieve a real estimation, great detail is required; therefore, a bottom-up approach has been chosen for the emissions' geographical characterization (Miola et al. 2010)

For site-specific air pollution externalities cost calculation, two estimates are critical: on the one hand, the quantity of pollutants emitted ( $\mathrm{PM}_{2,5}, \mathrm{SO}_{2}, \mathrm{NOx}$ and VOCs), and on the other hand, the impact of pollutants that are released. Well known projects already exist regarding both, for polluting emissions estimation as described in the EMEP/EEA Air Polluting Emissions Inventory Guidebook 2009, and for impact estimation, as described in the "Benefits Table Database: Estimates of the Marginal External Costs of Air Pollution in Europe (BETA)” and "Clean Air For Europe Program (CAFE)."

The Benefits Table Database (BETA 2002) provides a straightforward estimation of air pollution's overall external costs, putting together both urban and rural externalities. However, once new air pollution's external costs were published under the CAFE program (2011), experts agreed that previous rural external costs given by BETA were underestimating actual costs.

This paper maintains the methodology given by BETA to add urban and rural external costs, but takes updated rural external costs provided by the CAFE program. The cost estimation done under the CAFE program considers human exposure to $\mathrm{PM}_{2.5}$, human exposure to ozone, and exposure of crops to ozone. Although more impacts are known, still there is not sufficient information to evaluate them with sufficient accuracy. 
Moreover, in an attempt to achieve comprehensive results, the valuation done by the CAFE program considers four different sensitivity scenarios that lead to four different results for each geographical area being considered. The variation comes from different methodologies used to value mortality: mean or median values to estimate the value of a life year or the value of statistical life. Moreover the range of health effects and the cut point for ozone impact assessment also changes in each of the sensitivity scenarios.

On balance, the emissions impact assessment model is composed of a top-down approach regarding the emissions quantification and a bottom-up approach with regards to geographical characterization. In this manner, the model achieves a comprehensive assessment, taking into account the specifics of each emissions point as well as the details of the emitting vessel type. Finally, to obtain overall results, individual results for each of the considered geographical locations are aggregated.

\section{$3 \quad$ Case study}

This section provides a practical development of the theoretical methodology explained in the above section. For this purpose, the Spanish port system has been chosen due to data availability.

\subsection{Port network and traffic assessment}

As previously explained, an efficient measure needs target identification. Traffic in the Spanish port network is then analysed, looking for harbours with significant regular traffic shares. 2009 RoRo, passenger, and container ship traffics are revised.

\begin{tabular}{|c|c|c|c|c|c|c|c|c|c|}
\hline \multirow{2}{*}{ Port authority } & \multicolumn{5}{|c|}{ Total traffic } & \multicolumn{4}{|c|}{ Regular traffic } \\
\hline & Vessels & $\%$ & GT & $\%$ & $\begin{array}{l}\text { Average } \\
\text { GT }\end{array}$ & Vessels & $\%$ & GT & $\%$ \\
\hline Alicante & 935 & $1 \%$ & 14095052 & $1 \%$ & 15075 & 648 & $69 \%$ & 12447313 & $88 \%$ \\
\hline Almería & 1999 & $2 \%$ & 27595552 & $2 \%$ & 13805 & 1703 & $85 \%$ & 24976342 & $91 \%$ \\
\hline Bay of Algeciras & 24852 & $22 \%$ & 274917623 & $17 \%$ & 11062 & 20801 & $84 \%$ & 203161823 & $74 \%$ \\
\hline Bay of Cádiz & 1644 & $1 \%$ & 25365901 & $2 \%$ & 15429 & 1010 & $61 \%$ & 19745717 & $78 \%$ \\
\hline Balearic Islands & 7855 & $7 \%$ & 134291951 & $8 \%$ & 17096 & 6913 & $88 \%$ & 129679912 & $97 \%$ \\
\hline Barcelona & 8417 & $8 \%$ & 245192663 & $15 \%$ & 29131 & 6613 & $79 \%$ & 222031248 & $91 \%$ \\
\hline Ceuta & 12287 & $11 \%$ & 63298711 & $4 \%$ & 5152 & 8360 & $68 \%$ & 47739046 & $75 \%$ \\
\hline Las Palmas & 9679 & $9 \%$ & 164189885 & $10 \%$ & 16964 & 5124 & $53 \%$ & 112208434 & $68 \%$ \\
\hline Málaga & 1714 & $2 \%$ & 37073453 & $2 \%$ & 21630 & 1462 & $85 \%$ & 35847525 & $97 \%$ \\
\hline Melilla & 1244 & $1 \%$ & 14749044 & $1 \%$ & 11856 & 1192 & $96 \%$ & 14545660 & $99 \%$ \\
\hline S. C. de Tenerife & 15479 & $14 \%$ & 182979483 & $11 \%$ & 11821 & 13289 & $86 \%$ & 137933888 & $75 \%$ \\
\hline Valencia & 6806 & $6 \%$ & 177481599 & $11 \%$ & 26077 & 4913 & $72 \%$ & 156863283 & $88 \%$ \\
\hline Vigo & 1995 & $2 \%$ & 32596655 & $2 \%$ & 16339 & 1227 & $62 \%$ & 29315754 & $90 \%$ \\
\hline Selected ports & 94906 & $83 \%$ & 1393827572 & $86 \%$ & 14686 & 77151 & $68 \%$ & 1146495945 & $71 \%$ \\
\hline Spanish port network & 113717 & $100 \%$ & 1619334849 & $100 \%$ & & 113717 & & 1619334849 & \\
\hline
\end{tabular}

Table 3. Major regular traffic harbours in the Spanish port network, year 2009. Source: own, based on port authorities annual reports. 
The table above shows that the target identification criteria has been correct and useful, just 13 of the 28 port authorities in the Spanish port network with their regular traffic account for almost $70 \%$ of total port calls in the country.

The existing concentration, both in ship types and harbours for regular traffic, eases the implementation of alternative power supply measures. Action in target segments will optimize obtained results.

RoRo, passenger, and container ships port calls in the selected harbours are analysed in the following tables $(4,5$, and 6$)$ in order to gather all the necessary data for the estimation of emissions.

\begin{tabular}{|l|l|l|l|l|l|}
\hline \multirow{2}{*}{ Port authority } & \multicolumn{4}{|l}{ Ro-Ro } & \multicolumn{4}{ll}{ Average } \\
\cline { 2 - 6 } & Vessels & $\%$ & GT & $\%$ \\
\hline Alicante & 225 & $24 \%$ & 5108686 & $36 \%$ & 22705 \\
\hline Almería & 1625 & $81 \%$ & 23554108 & $85 \%$ & 14495 \\
\hline Bay of Algeciras & 817 & $3 \%$ & 8251255 & $3 \%$ & 10099 \\
\hline Bay of Cádiz & 470 & $29 \%$ & 6590236 & $26 \%$ & 14022 \\
\hline Balearic Islands & 1133 & $14 \%$ & 24025128 & $18 \%$ & 21205 \\
\hline Barcelona & 3429 & $41 \%$ & 92316798 & $38 \%$ & 26922 \\
\hline Ceuta & 593 & $5 \%$ & 3071222 & $5 \%$ & 5179 \\
\hline Las Palmas & 3174 & $33 \%$ & 52767523 & $32 \%$ & 16625 \\
\hline Málaga & 708 & $41 \%$ & 9689570 & $26 \%$ & 13686 \\
\hline Melilla & 887 & $71 \%$ & 12373352 & $84 \%$ & 13950 \\
\hline S. C. de Tenerife & 4750 & $31 \%$ & 70933262 & $39 \%$ & 14933 \\
\hline Valencia & 1693 & $25 \%$ & 43082510 & $24 \%$ & 25447 \\
\hline Vigo & 525 & $26 \%$ & 13235831 & $41 \%$ & 25211 \\
\hline Selected ports & 20029 & $93 \%$ & 364999481 & $93 \%$ & 18224 \\
\hline Spanish port network & 21423 & & 391188430 & & \\
\hline
\end{tabular}

Table 4. Ro-Ro traffic at selected Spanish ports in the year 2009. Source: own, based on port authorities' annual reports.

\begin{tabular}{|l|l|l|l|l|l|}
\hline \multirow{2}{*}{ Port authority } & \multicolumn{5}{|l|}{ Passenger } \\
\cline { 2 - 6 } & Vessels & $\%$ & GT & $\%$ & $\begin{array}{l}\text { Average } \\
\text { GT }\end{array}$ \\
\hline Alicante & 61 & $7 \%$ & 3516136 & $25 \%$ & 57642 \\
\hline Almería & 58 & $3 \%$ & 1293504 & $5 \%$ & 22302 \\
\hline Bay of Algeciras & 17931 & $72 \%$ & 125360610 & $46 \%$ & 6991 \\
\hline Bay of Cádiz & 229 & $14 \%$ & 9313119 & $37 \%$ & 40669 \\
\hline Balearic Islands & 5780 & $74 \%$ & 105654784 & $79 \%$ & 18279 \\
\hline Barcelona & 798 & $9 \%$ & 59504402 & $24 \%$ & 74567 \\
\hline Ceuta & 7618 & $62 \%$ & 43921170 & $69 \%$ & 5765 \\
\hline Las Palmas & 392 & $4 \%$ & 20719726 & $13 \%$ & 52856 \\
\hline Málaga & 485 & $28 \%$ & 18687367 & $50 \%$ & 38531 \\
\hline Melilla & 226 & $18 \%$ & 1468096 & $10 \%$ & 6496 \\
\hline S. C. de Tenerife & 7844 & $51 \%$ & 59667390 & $33 \%$ & 7607 \\
\hline Valencia & 196 & $3 \%$ & 5175532 & $3 \%$ & 26406 \\
\hline Vigo & 102 & $5 \%$ & 8809690 & $27 \%$ & 86370 \\
\hline Selected ports & 41720 & $99 \%$ & 463091526 & $98 \%$ & 11100 \\
\hline Spanish port network & 42098 & & 473133555 & & \\
\hline
\end{tabular}

Table 5. Passenger ship traffic at selected Spanish ports, year 2009. Source: own, based on port authorities' annual reports. 


\begin{tabular}{|l|l|l|l|l|l|}
\hline \multirow{2}{*}{ Port authority } & \multicolumn{4}{|l}{ Passenger } \\
\cline { 2 - 6 } & Vessels & $\%$ & GT & $\begin{array}{l}\text { Average } \\
\text { GT }\end{array}$ \\
\hline Alicante & 61 & $7 \%$ & 3516136 & $25 \%$ & 57642 \\
\hline Almería & 58 & $3 \%$ & 1293504 & $5 \%$ & 22302 \\
\hline Bay of Algeciras & 17931 & $72 \%$ & 125360610 & $46 \%$ & 6991 \\
\hline Bay of Cádiz & 229 & $14 \%$ & 9313119 & $37 \%$ & 40669 \\
\hline Balearic Islands & 5780 & $74 \%$ & 105654784 & $79 \%$ & 18279 \\
\hline Barcelona & 798 & $9 \%$ & 59504402 & $24 \%$ & 74567 \\
\hline Ceuta & 7618 & $62 \%$ & 43921170 & $69 \%$ & 5765 \\
\hline Las Palmas & 392 & $4 \%$ & 20719726 & $13 \%$ & 52856 \\
\hline Málaga & 485 & $28 \%$ & 18687367 & $50 \%$ & 38531 \\
\hline Melilla & 226 & $18 \%$ & 1468096 & $10 \%$ & 6496 \\
\hline S. C. de Tenerife & 7844 & $51 \%$ & 59667390 & $33 \%$ & 7607 \\
\hline Valencia & 196 & $3 \%$ & 5175532 & $3 \%$ & 26406 \\
\hline Vigo & 102 & $5 \%$ & 8809690 & $27 \%$ & 86370 \\
\hline \hline Selected ports & 41720 & $99 \%$ & 463091526 & $98 \%$ & 11100 \\
\hline Spanish port network & 42098 & & 473133555 & & \\
\hline
\end{tabular}

Table 6. Container ship traffic at selected Spanish ports, year 2009. Source: own, based on port authorities' annual reports.

Ship type disaggregation is important since ship characteristics (engine type and power) and hoteling and manoeuvring times are ship type related.

Both main and auxiliary engines need to be characterized, ME and AE from now on respectively. The majority of vessels that form a part of both Ro-Ro and Passenger ship fleets are equipped with Medium Speed Diesel (MSD) ME and MSD or High Speed Diesel (HSD) AE. Therefore, the emissions factors for these two types of fleets are equal. On the other hand, the container ship fleet is on average equipped with Slow Speed Diesel (SSD) ME and MSD or HSD AE (Lloyd's Marine Intelligence Unit database 2009), resulting in different emission factors when compared with passenger and Ro-Ro ships.

The following tables gather the emission factors used in the calculation. These have been updated for the year 2009 from emissions factors given by ENTEC for the year 2005. All of them correspond to Marine Gas Oil (MGO), as regulations in 2009 did not permit sulphur content above $0,2 \%$ at port.

\begin{tabular}{|l|l|l|l|l|l|}
\hline \multicolumn{1}{|c|}{ Ship Type } & \multicolumn{1}{|c|}{ ME } & $\mathbf{P M}_{2, \mathbf{5}}(\mathbf{g} / \mathbf{k W} \cdot \mathbf{h})$ & $\mathbf{S O}_{\mathbf{2}} \mathbf{( g / \mathbf { k W }}$.h) & NOx $(\mathbf{g} / \mathbf{k W} \cdot \mathbf{h})$ & VOCs $(\mathbf{g} / \mathbf{k W} \cdot \mathbf{h})$ \\
\hline Ro-Ro & MSD & 0,81 & 0,9 & 9,95 & 1,5 \\
\hline Passenger & MSD & 0,81 & 0,9 & 9,95 & 1,5 \\
\hline Container & SSD & 0,81 & 0,8 & 12,77 & 1,8 \\
\hline
\end{tabular}

Table 7. Emissions factors of ME burning MGO in manoeuvring and hoteling phases. Source: own, based on ENTEC 2005. 


\begin{tabular}{|l|c|l|l|l|l|}
\hline \multicolumn{1}{|c|}{ Ship Type } & AE & $\mathbf{P M}_{2,5}$ (g/kW.h) & $\mathbf{S O}_{\mathbf{2}} \mathbf{( g / k W \cdot h )}$ & NOx $\mathbf{( g / k W . h )}$ & VOCs $\mathbf{~ g / k W . h ) ~}$ \\
\hline Ro-Ro & MSD/HSD & 0,27 & 0,9 & 13,05 & 0,4 \\
\hline Passenger & MSD/HSD & 0,27 & 0,9 & 13,05 & 0,4 \\
\hline Container & MSD/HSD & 0,27 & 0,9 & 13,05 & 0,4 \\
\hline
\end{tabular}

Table 8.Emissions factors of AE burning MGO in cruise, manoeuvring and hoteling phases. Source: own, based on ENTEC 2005.

Since engine power is unknown and only GT is available, engine power has to be estimated using the formulas detailed in the table below.

\begin{tabular}{|l|l|l|}
\hline Ship categories & Installed main engine power & $\begin{array}{l}\text { Estimated average power vessel ratio of } \\
\text { Auxiliary Engines/Main Engine }\end{array}$ \\
\hline Container & $2,9165 \cdot \mathrm{GT}^{0.8719}$ & 0,25 \\
\hline Ro-Ro Cargo & $164,578 \cdot \mathrm{GT}^{0.4350}$ & 0,24 \\
\hline Passenger & $9,55078 \cdot \mathrm{GT}^{0.7570}$ & 0,16 \\
\hline
\end{tabular}

Table 9. Installed main engine power as a function of gross tonnage and estimated average power vessel ratio of auxiliary engines/main engine. Source: Study for 2010 and 1997 world fleets: ENTEC (2007) for 2006 Mediterranean Sea Fleet.

Auxiliary engines are operated both during manoeuvring and hoteling phases, although they contribute more while at berth (when the main engine is shut down). Hoteling and manoeuvring times for each vessel category are based on average values and are reported in the following table:

\begin{tabular}{|l|l|l|}
\hline Ship categories & Maneuvering time (h) & Hotelling time (h) \\
\hline Container & 1 & 14 \\
\hline Ro-Ro Cargo & 1 & 15 \\
\hline Passenger & 0,8 & 14 \\
\hline
\end{tabular}

Table 10. Assumptions for the average duration of port activities. Source: ENTEC 2002

ME and AE load factors at different navigation phases necessary for calculation are shown in the table below:

\begin{tabular}{|l|l|l|l|}
\hline Phase & \% load of MCR of ME & $\begin{array}{l}\text { \% time all ME } \\
\text { operating }\end{array}$ & \% load of MCR of AE \\
\hline Maneuvering & 100 & 50 \\
\hline Hotelling & 20 & 5 & 40 \\
\hline
\end{tabular}

Table 11. Estimated \% load Maximum Continuous Rating (MCR) of Main Engine (ME) and Auxiliary Engine (AE) for different navigation phases. Source: ENTEC 2002

The Tier 3 approach calculates the emissions (E) on a single trip basis, considering the three different navigation phases of a journey.

\section{Etrip $=$ Ehotelling + Emaneuvering + Ecruising}

Once all the necessary variables are known, the following formula corresponding to Tier 3 methodology is applied. As a result, emissions for each of the harbours, ship types, and pollutants being considered are obtained. 


$$
\begin{array}{ll}
E_{p o r t, i, s, m}=\sum_{p}\left[T_{p} \sum_{e}\left(P_{e} \times L F_{e, p} \times E F_{e, i, s, m, p}\right)\right] \\
\\
\mathrm{E}_{\text {port }} \quad \text { emissions at port (tons) } \\
\mathrm{EF} & \text { emissions factor (tons/kWh) } \\
\mathrm{LF} & \text { engine load factor (\%) } \\
\mathrm{P} & \text { nominal engine power (kW) } \\
\mathrm{T} & \text { time (hours) } \\
\mathrm{e} & \text { engine (main, auxiliary) } \\
\mathrm{i} & \text { pollutant (PM } \left.\mathrm{PM}_{2,5}, \mathrm{SO}_{2}, \mathrm{NOx}, \mathrm{VOC}\right) \\
\mathrm{s} & \text { ship type (Ro-Ro, Passenger, Container) } \\
\mathrm{m} & \text { fuel type (Bunker Fuel Oil, Marine Diesel Oil, Marine Gas Oil) } \\
\mathrm{p} & \text { trip phase (cruise, manoeuvring, hoteling) }
\end{array}
$$

The next step is to evaluate the impact of the emissions, which are estimated using BETA and CAFE projects.

Both local and rural impacts are estimated. For local impact estimation, as set in the BETA project, urban externalities for $\mathrm{PM}_{2,5}$ and $\mathrm{SO}_{2}$ in a standard city with a population of 100.000 people are multiplied by the corresponding factors, depending on the population around the selected harbour. Then the country-specific rural impact is added. For this purpose, rural impact given for Spain in the CAFE project is used. As mentioned in the methodology, the CAFE project lists four different rural impacts based on different sensitivity ranges.

\begin{tabular}{|l|l|l|l|}
\hline Population & Factor & $\mathbf{P M}_{2.5}(\boldsymbol{\epsilon} / \mathbf{t m})$ & $\mathbf{S O}_{\mathbf{2}}(\boldsymbol{\epsilon} / \mathbf{t m})$ \\
\hline $\begin{array}{l}\text { Standard city with a population of } 100.000 \\
\text { people }\end{array}$ & 1 & $33.000 €$ & $6.000 €$ \\
\hline 500.000 & 5 & $165.000 €$ & $30.000 €$ \\
\hline 1.000 .000 & 7,5 & $247.500 €$ & $45.000 €$ \\
\hline Several million people & 15 & $495.000 €$ & $90.000 €$ \\
\hline
\end{tabular}

Table 12. Local impact calculation factors. Source: Holland, M.R. and Watkiss, P. Benefits Table database: Estimates of the marginal external costs of air pollution in Europe, 2002

\begin{tabular}{|l|l|l|l|l|}
\hline Scenario & $\mathbf{P M}_{\mathbf{2 . 5}}(\boldsymbol{(} / \mathbf{t m})$ & $\mathbf{S O}_{\mathbf{2}}(\boldsymbol{\epsilon} / \mathbf{t m})$ & NOx $(\boldsymbol{\epsilon} / \mathbf{t m})$ & VOCs $(\boldsymbol{\epsilon} / \mathbf{t m})$ \\
\hline Sensitivity case 1 & $19.000 €$ & $4.300 €$ & $2.600 €$ & $380 €$ \\
\hline Sensitivity case 2 & $29.000 €$ & $6.600 €$ & $3.800 €$ & $510 €$ \\
\hline Sensitivity case 3 & $37.000 €$ & $8.400 €$ & $5.200 €$ & $920 €$ \\
\hline Sensitivity case 4 & $54.000 €$ & $12.000 €$ & $7.200 €$ & $1.100 €$ \\
\hline
\end{tabular}

Table 13. Rural impact per ton of pollutant emitted. Source: Holland M. et al. Damages per ton of $\mathrm{PM}_{2,5}$, $\mathrm{SO}_{2}, \mathrm{NO}_{\mathrm{X}}$, and VOC-s emissions from each EU25 Member State (excluding Cyprus) and surrounding seas.

As mentioned previously, local impact is only produced by $\mathrm{PM}_{2,5}$, and $\mathrm{SO}_{2}$. $\mathrm{NOx}$, and VOC-s are only relevant to rural impact. 


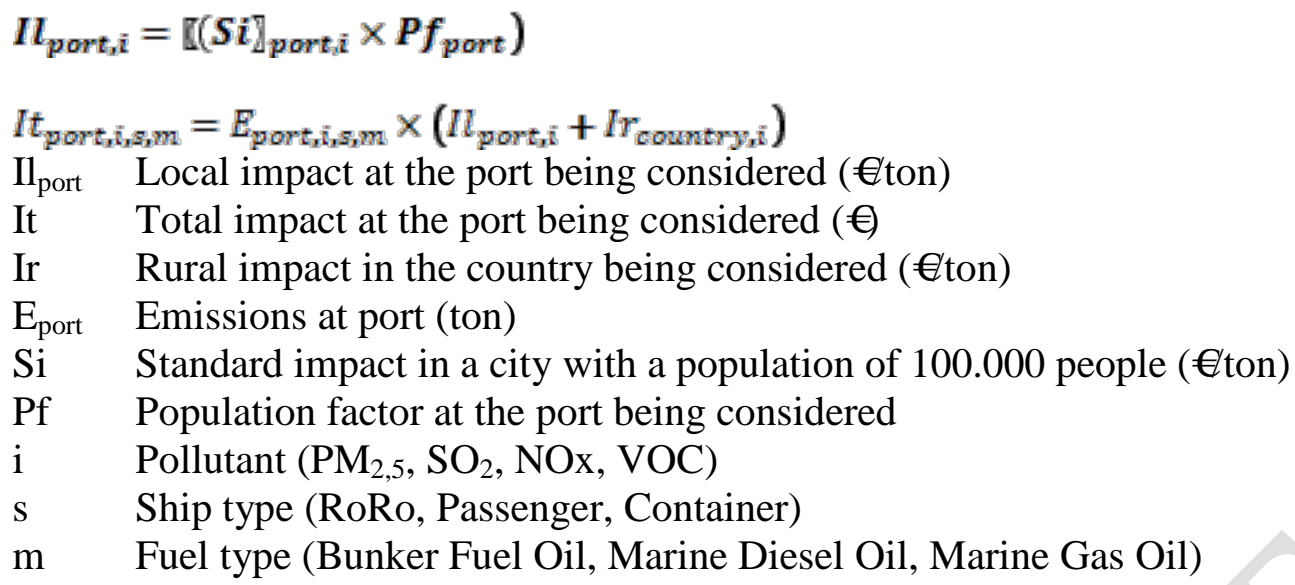

External costs estimation of emissions to air from shipping has been done based on a meta-analysis of existing economic literature on the subject (BETA and CAFE projects). Externalities from emissions to air do follow pollutants concentration levels; however pollutant emissions and pollutant concentrations do not follow a linear relationship.

In this respect the rural impact estimation from air pollutant emissions from shipping does not present major shortcomings as the CAFE project using the EMEP dispersion model presents sufficient resolution. On the other hand for the local impact assessment a more refined resolution is needed as the baseline pollutant concentration together with local meteorological conditions can critically affect pollutants emissions impact.

Nevertheless, due to the study's national scope and as a first insight into in-port emissions impact, considered assumptions are regarded valid. 


\section{Results}

Emissions are estimated according to formulas reported in the above section.

\begin{tabular}{|c|c|c|c|c|c|c|c|c|c|c|c|c|}
\hline \multirow{2}{*}{ Target ports } & \multicolumn{4}{|c|}{ Ro-Ro ships } & \multicolumn{4}{|c|}{ Passenger ships } & \multicolumn{4}{|c|}{ Container ships } \\
\hline & $\mathbf{P M}_{2.5}$ & $\mathrm{SO}_{2}$ & NOx & VOC & $\mathbf{P M}_{2.5}$ & $\mathrm{SO}_{2}$ & NOx & VOC & $\mathbf{P M}_{2.5}$ & $\mathrm{SO}_{2}$ & NOx & VOC \\
\hline Alicante & 2,1 & 5 & 69,3 & 3,3 & 1,2 & 2,7 & 36,3 & 2 & 1,4 & 4,7 & 67,7 & 2,1 \\
\hline Almería & 12,2 & 29,7 & 411,8 & 19,9 & 0,5 & 1,2 & 16,8 & 0,9 & 0,1 & 0,2 & 2,4 & 0,1 \\
\hline B. of Algeciras & 5,2 & 12,8 & 176,9 & 8,5 & 70 & 157 & 2161,1 & 116,2 & 22 & 73,2 & 1061,1 & 32,5 \\
\hline B. of Cádiz & 3,5 & 8,5 & 117,4 & 5,7 & 3,4 & 7,7 & 104,7 & 5,6 & 1,4 & 4,6 & 66,7 & 2 \\
\hline Balearic Islands & 10 & 24,4 & 338,8 & 16,3 & 46,7 & 105,4 & 1442 & 77,5 & 0 & 0 & 0 & 0 \\
\hline Barcelona & 33,6 & 82 & 1137,5 & 54,8 & 18,7 & 42,2 & 577,1 & 31 & 22,6 & 75,2 & 1090,7 & 33,4 \\
\hline Ceuta & 2,8 & 6,9 & 96 & 4,6 & 25,7 & 58 & 793,5 & 42,7 & 0,3 & 1 & 14,6 & 0,4 \\
\hline Las Palmas & 25,2 & 61,6 & 853,7 & 41,2 & 7,1 & 16 & 218,5 & 11,7 & 12,7 & 42,4 & 614,7 & 18,8 \\
\hline Málaga & 5,2 & 12,6 & 174 & 8,4 & 6,9 & 15,6 & 212,8 & 11,4 & 2,4 & 8,1 & 116,9 & 3,6 \\
\hline Melilla & 6,5 & 15,9 & 221,1 & 10,7 & 0,8 & 1,9 & 25,8 & 1,4 & 0,3 & 0,9 & 12,7 & 0,4 \\
\hline S. C. de Tenerife & 36 & 87,9 & 1219,4 & 58,8 & 32,6 & 73,7 & 1007,7 & 54,2 & 2,7 & 9 & 129,9 & 4 \\
\hline Valencia & 16,2 & 39,5 & 548 & 26,4 & 2,1 & 54,7 & 64,6 & 3,5 & 34,0 & 113,4 & 1644,6 & 50,4 \\
\hline Vigo & 5 & 12,2 & 169,3 & 8,2 & 2,7 & 6 & 82,4 & 4,4 & 2,6 & 8,7 & 126,5 & 3,9 \\
\hline
\end{tabular}

Table 14. Annual polluting emissions for selected ships and ports for the year 2009. Source: own.

Analysing ship types separately, passenger ships released 41\%, Ro-Ro ships 33\%, and container ships $25 \%$ of total emissions at the harbours and traffics considered.

As shown in the figure below, most of the emissions in mass, almost $90 \%$, correspond to NOx. However, this does not mean that most of the impact produced is derived from them.

Emission factors do not differ much between ship types, although the quantity of emitted pollutants can vary significantly due to important differences in engine power and turnaround times (manoeuvrings + hoteling). In this respect, among the studied fleets, on average, container ships double the engine power of passenger and Ro-Ro ships. Therefore, for an equal number of port calls and turnaround times, this kind of ships present approximately twice as much emissions.

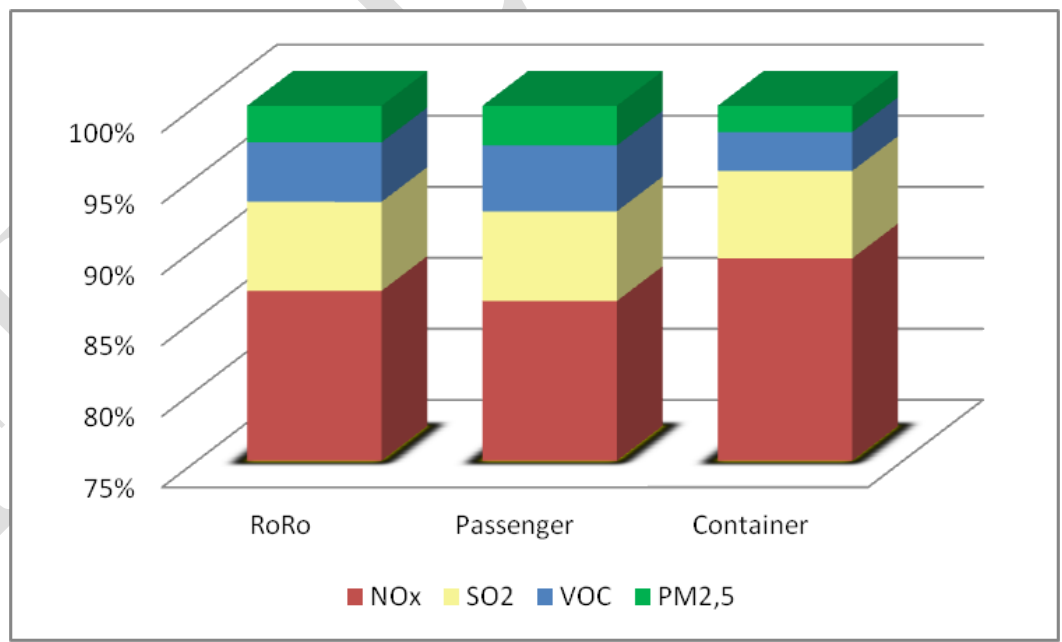

Figure 1.Pollutant mass share by ship type. Source: own. 


\begin{tabular}{|l|l|l|l|l|}
\hline \multirow{2}{*}{ Target ports } & \multicolumn{4}{|l|}{ Regular traffic (tons/year) } \\
\cline { 2 - 5 } & $\mathbf{P M}_{2.5}$ & $\mathbf{S O}_{2}$ & NOx & VOC-s \\
\hline Alicante & 6,2 & 14 & 155,0 & 9,1 \\
\hline Almería & 14,2 & 31 & 361,2 & 20,9 \\
\hline B. Algeciras & 124,3 & 263 & 3017,2 & 184,4 \\
\hline B. Cádiz & 10,2 & 22 & 252,2 & 15,0 \\
\hline Balearic Islands & 63,0 & 131 & 1504,9 & 93,9 \\
\hline Barcelona & 100,0 & 219 & 2508,3 & 147,2 \\
\hline Ceuta & 32,3 & 67 & 766,7 & 48,1 \\
\hline Las Palmas & 59,5 & 131 & 1501,2 & 87,5 \\
\hline Málaga & 17,9 & 38 & 441,1 & 26,5 \\
\hline Melilla & 8,7 & 19 & 219,3 & 12,8 \\
\hline S. C. de Tenerife & 81,3 & 174 & 2001,1 & 120,3 \\
\hline Valencia & 45,6 & 70 & 799,9 & 72,0 \\
\hline Vigo & 13,4 & 29 & 335,3 & 19,7 \\
\hline \hline Total & 576,4 & 1209,20 & 13863,5 & 857,3 \\
\hline
\end{tabular}

Table 15. Total annual pollution emissions per harbour, year 2009. Source: own.

Once emissions are known and taking into account the sensitivity of the emission site, considering the number of inhabitants being affected (local impact) and the countryspecific rural impact, the impact produced by them is evaluated. 


\begin{tabular}{|c|c|c|c|c|c|c|c|c|}
\hline & \multirow{2}{*}{ Spanish ports } & \multirow{2}{*}{$\begin{array}{l}\text { Inhabitants in } \\
\text { urban area }\end{array}$} & \multicolumn{2}{|l|}{$\mathbf{P M}_{2.5}$} & \multicolumn{2}{|l|}{$\mathrm{SO}_{2}$} & \multirow{2}{*}{ NOx } & \multirow{2}{*}{ VOC-s } \\
\hline & & & Local & Rural & Local & Rural & & \\
\hline Sensivity case 1 & \multirow{4}{*}{ Alicante } & \multirow{4}{*}{334418} & $110.358 €$ & $19.000 €$ & $20.065 €$ & $4.300 €$ & $2.600 €$ & $380 €$ \\
\hline Sensivity case 2 & & & $110.358 €$ & $29.000 €$ & $20.065 €$ & $6.600 €$ & $3.800 €$ & $510 €$ \\
\hline Sensivity case 3 & & & $110.358 €$ & $37.000 €$ & $20.065 €$ & $8.400 €$ & $5.200 €$ & $920 €$ \\
\hline Sensivity case 4 & & & $110.358 €$ & $54.000 €$ & $20.065 €$ & $12.000 €$ & $7.200 €$ & $1.100 €$ \\
\hline Sensivity case 1 & \multirow{4}{*}{ Almería } & \multirow{4}{*}{190013} & $62.704 €$ & $19.000 €$ & $11.401 €$ & $4.300 €$ & $2.600 €$ & $380 €$ \\
\hline Sensivity case 2 & & & $62.704 €$ & $29.000 €$ & $11.401 €$ & $6.600 €$ & $3.800 €$ & $510 €$ \\
\hline Sensivity case 3 & & & $62.704 €$ & $37.000 €$ & $11.401 €$ & $8.400 €$ & $5.200 €$ & $920 €$ \\
\hline Sensivity case 4 & & & $62.704 €$ & $54.000 €$ & $11.401 €$ & $12.000 €$ & $7.200 €$ & $1.100 €$ \\
\hline Sensivity case 1 & \multirow{4}{*}{ Bay of Algeciras } & \multirow{4}{*}{116417} & $38.418 €$ & $19.000 €$ & $6.985 €$ & $4.300 €$ & $2.600 €$ & $380 €$ \\
\hline Sensivity case 2 & & & $38.418 €$ & $29.000 €$ & $6.985 €$ & $6.600 €$ & $3.800 €$ & $510 €$ \\
\hline Sensivity case 3 & & & $38.418 €$ & $37.000 €$ & $6.985 €$ & $8.400 €$ & $5.200 €$ & $920 €$ \\
\hline Sensivity case 4 & & & $38.418 €$ & $54.000 €$ & $6.985 €$ & $12.000 €$ & $7.200 €$ & $1.100 €$ \\
\hline Sensivity case 1 & \multirow{4}{*}{ Bay of Cádiz } & \multirow{4}{*}{125826} & $41.523 €$ & $19.000 €$ & $7.550 €$ & $4.300 €$ & $2.600 €$ & $380 €$ \\
\hline Sensivity case 2 & & & $41.523 €$ & $29.000 €$ & $7.550 €$ & $6.600 €$ & $3.800 €$ & $510 €$ \\
\hline Sensivity case 3 & & & $41.523 €$ & $37.000 €$ & $7.550 €$ & $8.400 €$ & $5.200 €$ & $920 €$ \\
\hline Sensivity case 4 & & & $41.523 €$ & $54.000 €$ & $7.550 €$ & $12.000 €$ & $7.200 €$ & $1.100 €$ \\
\hline Sensivity case 1 & \multirow{4}{*}{ Balearic Islands } & \multirow{4}{*}{502359} & $252.057 €$ & $19.000 €$ & $53.276 €$ & $4.300 €$ & $2.600 €$ & $380 €$ \\
\hline Sensivity case 2 & & & $252.057 €$ & $29.000 €$ & $53.276 €$ & $6.600 €$ & $3.800 €$ & $510 €$ \\
\hline Sensivity case 3 & & & $252.057 €$ & $37.000 €$ & $53.276 €$ & $8.400 €$ & $5.200 €$ & $920 €$ \\
\hline Sensivity case 4 & & & $252.057 €$ & $54.000 €$ & $53.276 €$ & $12.000 €$ & $7.200 €$ & $1.100 €$ \\
\hline Sensivity case 1 & \multirow{4}{*}{ Barcelona } & \multirow{4}{*}{1619337} & $400.786 €$ & $19.000 €$ & $72.870 €$ & $4.300 €$ & $2.600 €$ & $380 €$ \\
\hline Sensivity case 2 & & & $400.786 €$ & $29.000 €$ & $72.870 €$ & $6.600 €$ & $3.800 €$ & $510 €$ \\
\hline Sensivity case 3 & & & $400.786 €$ & $37.000 €$ & $72.870 €$ & $8.400 €$ & $5.200 €$ & $920 €$ \\
\hline Sensivity case 4 & & & $400.786 €$ & $54.000 €$ & $72.870 €$ & $12.000 €$ & $7.200 €$ & $1.100 €$ \\
\hline Sensivity case 1 & & & $26.588 €$ & $19.000 €$ & $4.834 €$ & $4.300 €$ & $2.600 €$ & $380 €$ \\
\hline Sensivity case 2 & Centa & 80570 & $26.588 €$ & $29.000 €$ & $4.834 €$ & $6.600 €$ & $3.800 €$ & $510 €$ \\
\hline Sensivity case 3 & Centa & & $26.588 €$ & $37.000 €$ & $4.834 €$ & $8.400 €$ & $5.200 €$ & $920 €$ \\
\hline Sensivity case 4 & & & $26.588 €$ & $54.000 €$ & $4.834 €$ & $12.000 €$ & $7.200 €$ & $1.100 €$ \\
\hline Sensivity case 1 & & & $190.762 €$ & $19.000 €$ & $34.684 €$ & $4.300 €$ & $2.600 €$ & $380 €$ \\
\hline Sensivity case 2 & Las Palmas & 578066 & $190.762 €$ & $29.000 €$ & $34.684 €$ & $6.600 €$ & $3.800 €$ & $510 €$ \\
\hline Sensivity case 3 & Las raimas & J/8000 & $190.762 €$ & $37.000 €$ & $34.684 €$ & $8.400 €$ & $5.200 €$ & $920 €$ \\
\hline Sensivity case 4 & & & $190.762 €$ & $54.000 €$ & $34.684 €$ & $12.000 €$ & $7.200 €$ & $1.100 €$ \\
\hline Sensivity case 1 & & & $176.304 €$ & $19.000 €$ & $32.055 €$ & $4.300 €$ & $2.600 €$ & $380 €$ \\
\hline Sensivity case 2 & Málaga & 568507 & $176.304 €$ & $29.000 €$ & $32.055 €$ & $6.600 €$ & $3.800 €$ & $510 €$ \\
\hline Sensivity case 3 & Malaga & 568507 & $176.304 €$ & $37.000 €$ & $32.055 €$ & $8.400 €$ & $5.200 €$ & $920 €$ \\
\hline Sensivity case 4 & & & $176.304 €$ & $54.000 €$ & $32.055 €$ & $12.000 €$ & $7.200 €$ & $1.100 €$ \\
\hline Sensivity case 1 & & & $24.242 €$ & $19.000 €$ & $4.408 €$ & $4.300 €$ & $2.600 €$ & $380 €$ \\
\hline Sensivity case 2 & Melilla & 73460 & $24.242 €$ & $29.000 €$ & $4.408 €$ & $6.600 €$ & $3.800 €$ & $510 €$ \\
\hline Sensivity case 3 & Melilla & 73460 & $24.242 €$ & $37.000 €$ & $4.408 €$ & $8.400 €$ & $5.200 €$ & $920 €$ \\
\hline Sensivity case 4 & & & $24.242 €$ & $54.000 €$ & $4.408 €$ & $12.000 €$ & $7.200 €$ & $1.100 €$ \\
\hline Sensivity case 1 & & & $88.521 €$ & $19.000 €$ & $16.095 €$ & $4.300 €$ & $2.600 €$ & $380 €$ \\
\hline Sensivity case 2 & Santa Cruz de Tenerife & & $88.521 \epsilon$ & $29.000 €$ & $16.095 €$ & $6.600 €$ & $3.800 €$ & $510 €$ \\
\hline Sensivity case 3 & Santa Cruz de Tenerife & 268246 & $88.521 €$ & $37.000 €$ & $16.095 €$ & $8.400 €$ & $5.200 €$ & $920 €$ \\
\hline Sensivity case 4 & & & $88.521 €$ & $54.000 €$ & $16.095 €$ & $12.000 €$ & $7.200 €$ & $1.100 €$ \\
\hline Sensivity case 1 & & & $216.018 €$ & $19.000 €$ & $39.276 €$ & $4.300 €$ & $2.600 €$ & $380 €$ \\
\hline Sensivity case 2 & & & $216.018 €$ & $29.000 €$ & $39.276 €$ & $6.600 €$ & $3.800 €$ & $510 €$ \\
\hline Sensivity case 3 & Valencia & 809267 & $216.018 €$ & $37.000 €$ & $39.276 €$ & $8.400 €$ & $5.200 €$ & $920 €$ \\
\hline Sensivity case 4 & & & $216.018 €$ & $54.000 €$ & $39.276 €$ & $12.000 €$ & $7.200 €$ & $1.100 €$ \\
\hline Sensivity case 1 & & & $98.051 €$ & $19.000 €$ & $17.827 €$ & $4.300 €$ & $2.600 €$ & $380 €$ \\
\hline Sensivity case 2 & Viao & & $98.051 €$ & $29.000 €$ & $17.827 €$ & $6.600 €$ & $3.800 €$ & $510 €$ \\
\hline Sensivity case 3 & Vigo & 297124 & $98.051 €$ & $37.000 €$ & $17.827 €$ & $8.400 €$ & $5.200 €$ & $920 €$ \\
\hline Sensivity case 4 & & & $98.051 €$ & $54.000 €$ & $17.827 €$ & $12.000 €$ & $7.200 €$ & $1.100 €$ \\
\hline
\end{tabular}

Table 16.Local and rural impact on target harbours per pollutant emitted. Source: own 
The results obtained reflect that local impacts vary critically in the Spanish port network due to site sensitivity differences. The local impact in Barcelona is for instance 76 times higher than the one in Pasajes.

On the other hand, the rural impact is common for all harbours, although the impact in the most sensitive scenario is three times higher than the impact in the less sensitive scenario.

Finally, as both the quantity of emitted pollutants and the emissions impact are known, the external costs produced are quantified. Four different results emerge corresponding to the different sensitivity scenarios being considered.

\begin{tabular}{|c|c|c|c|c|c|c|}
\hline & \multirow{2}{*}{ Sensitivity cases } & \multicolumn{4}{|c|}{ Impact per pollutant } & \multirow[t]{2}{*}{ Total Impact } \\
\hline & & $\mathbf{P M}_{2.5}$ & $\mathrm{SO}_{2}$ & NOx & VOC-s & \\
\hline \multirow{8}{*}{$\begin{array}{l}\text { Selected } \\
\text { harbors }\end{array}$} & Sensitivity case 1 & $89.604 .444 €$ & $44.353 .668 €$ & $44.787 .494 €$ & $278.019 €$ & $179.023 .626 €$ \\
\hline & Sensitivity case 2 & $94.447 .104 €$ & $47.190 .136 €$ & $65.458 .645 €$ & $373.131 €$ & $207.469 .016 €$ \\
\hline & Sensitivity case 3 & $98.321 .232 €$ & $49.409 .980 €$ & $89.574 .988 €$ & $673.099 €$ & $237.979 .299 €$ \\
\hline & Sensitivity case 4 & $106.553 .754 €$ & $53.849 .667 €$ & $124.026 .907 €$ & $804.793 €$ & $285.235 .120 €$ \\
\hline & Sensitivity case 1 & $\begin{array}{l}50,1 \% \\
\end{array}$ & $24,8 \%$ & $25,0 \%$ & $0,2 \%$ & $100,0 \%$ \\
\hline & Sensitivity case 2 & $45,5 \%$ & $22,7 \%$ & $31,6 \%$ & $0,2 \%$ & $100,0 \%$ \\
\hline & Sensitivity case 3 & $41,3 \%$ & $20,8 \%$ & $37,6 \%$ & $0,3 \%$ & $100,0 \%$ \\
\hline & Sensitivity case 4 & $37,4 \%$ & $18,9 \%$ & $43,5 \%$ & $0,3 \%$ & $100,0 \%$ \\
\hline
\end{tabular}

Table 17. Impact on target harbours per emitted pollutant and year. Source: own.

Final figures are not the same in all sensitivity cases, not only with regards to the overall impact, but also regarding the impact share corresponding to each pollutant. The share of local impact decreases insofar as changing from sensitivity case 1 to 4 . This could have been expected since sensitivity scenarios have only been considered for rural impact.

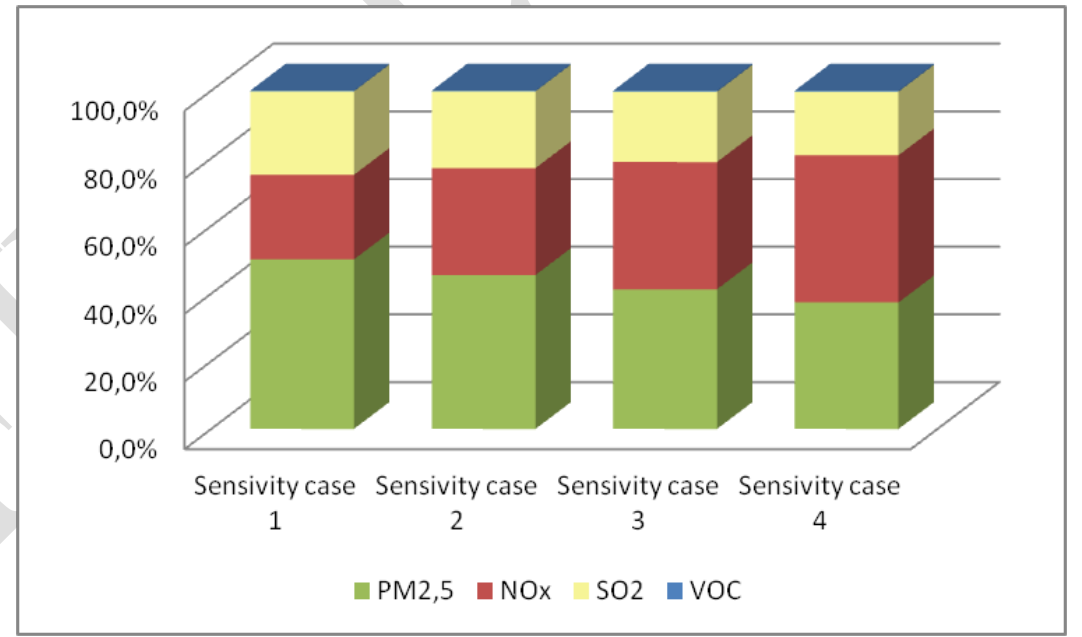

Figure 2. Pollutant impact share on the sensitivity cases being considered. Source: own. 


\section{Conclusions}

This study develops a smart port and traffic identification model to assist in the decision-making process that the implementation of alternative power supply measures require. The model identifies 13 Spanish harbours out of 28 and three ship types (RoRo, container, and passenger) out of a group of nine, accounting for almost $70 \%$ of total port calls in the Spanish port system as ideal candidates for alternative power supply.

2009 air pollution emissions have been quantified for selected harbours, accounting for over 16.500 tons. The main pollutant regarding emitted quantity was NOx, representing $86 \%$ of total emissions, due to its higher emission factor if compared with the rest of considered pollutants.

With regards to air pollutants emissions, turnaround time and engine power turn to be dominant factors. Both of them are directly proportional to emissions and, since they can vary greatly, they produce significant alterations on emissions.

Among the studied pollutants, $\mathrm{PM}_{2,5}$ and $\mathrm{NOx}$ are the ones presenting higher externalities. $\mathrm{PM}_{2,5}$ impact is always relevant. However, NOx's importance varies significantly, depending on the chosen sensitivity scenario. On the other hand, VOC emissions are irrelevant due to their low impact and small amount of emissions. For instance, considering sensitivity case 2, the overall externalities were valued at almost 206 million euros, whereas the individual contribution of $\mathrm{PM}_{2,5}, \mathrm{SO}_{2}$ and $\mathrm{NOx}$ was of 95, 65 and 46 million euros respectively.

In all cases, local impact, produced by $\mathrm{PM}_{2,5}$ and $\mathrm{SO}_{2}$ emissions, is predominant. Nevertheless, rural impact turns significant in case of choosing the most sensitive scenarios.

Dealing with air pollution impacts the most critical and decisive variable is the population exposed to it. The resulting impact from air pollution emissions increases lineally as the exposed population grows. Population density around harbours is crucial.

According to the Annual EU GHG inventory 1990-2008 and inventory report 2010 (EC 2010), in 2009 the emissions of NOx and $\mathrm{SO}_{2}$ in Spain were of 1066 and 431 thousand tons respectively. This means that the shipping activity in selected ports contributes with $1,3 \%$ and $0,28 \%$, to the national $\mathrm{NOx}$ and $\mathrm{SO}_{2}$ emission inventory respectively.

Although port emissions are not a predominant emission source within the national inventory, this paper highlights the fact that ship air pollution in harbour areas is already significant. Its impact is serious, even more if ship traffic growing trend is taken into account, and therefore, prompt policy instruments are necessary. In this respect, the paper calls national and international maritime policy makers to work on the issue. A consensus exists in current literature promoting integrated measures and instruments as the best known method to reduce ship air pollution against single and independent policy instruments. Special control areas with more stringent measures are needed in harbours located close to densely populated areas, as these locations are more sensitive to polluting emissions.

Moreover, the obtained results show that a big budget exists for intervening actions. Although cost-benefit analyses are always required before introducing measures aiming to enhance the environmental performance of ships at port. For instance, cold ironing could improve significantly ships' environmental performance at port.

\section{$6 \quad$ Future research}


Within the scenario described in this paper, followed by a body of international regulation that restricts the emissions levels from ships at ports, the challenge for the fleets and ports is not only technical, but also economic and logistical. There are different measures that can be taken while at berth that serve to accomplish current and future regulations: on the one hand, use of low sulphur content fuels, changes in engines like scrubbers, use of alternative fuels, such as methane gas or second and third generation biofuels; on the other hand, the selection of air emission controls for a vessel (Balland, Erikstad, and Fagerholt 2012) berth or ports can also use shore power measures that offer multiple benefits, such as the reduction on fuel expenses, emissions and also reductions in noise levels associated to AE operation.

The Transmar Research Group of the Nautical Sciences and Engineering Department at the Universitat Politècnica de Catalunya (DCEN - UPC) is now evaluating the use of methane gas as an ideal fuel to comply with current and future regulations at port. Analyses that are being carried out currently are developing a proposal for an assessment model to validate the economical and operational viability of providing methane gas to ships berthed at the Port of Castellón (Spanish Mediterranean coast) (Aizpuru 2011). Savings expected from using methane gas instead of marine gas oil are more than $2 \mathrm{MTm}$ of $\mathrm{CO}_{2}$ per year, besides the radical reduction of particle and sulphur emissions. Future research based on this model is expected to be adapted to different Spanish ports. 


\section{Glossary}

\begin{tabular}{|l|l|}
\hline $\mathrm{SO}_{2}$ & Sulphur Dioxide \\
\hline $\mathrm{NOx}$ & Nitrogen Oxides \\
\hline $\mathrm{PM}_{2,5}$ & Particulate Matter \\
\hline $\mathrm{VOC}-\mathrm{s}$ & Volatile Organic Compounds \\
\hline $\mathrm{IMO}$ & International Maritime Organization \\
\hline$M E P C$ & $\begin{array}{l}\text { Marine Environment and Protection } \\
\text { Committee }\end{array}$ \\
\hline$E C A$ & Emissions control areas \\
\hline$E U$ & European Union \\
\hline$E C$ & European Commission \\
\hline$R o-R o$ & Roll On - Roll Off \\
\hline$S O x$ & Sulphur Oxides \\
\hline$G T$ & Gross Tonnage \\
\hline$M C R$ & Maximum continuous rating \\
\hline$E$ & Emissions \\
\hline$T$ & Time \\
\hline$M a n$ & Maneuvering \\
\hline Hot & Hoteling \\
\hline$M E$ & Main Engine \\
\hline$A E$ & Auxiliary Engine \\
\hline$M G O$ & Marine Gas Oil \\
\hline$S S D$ & Slow Speed Diesel \\
\hline$M S D$ & Medium Speed Diesel \\
\hline$H S D$ & High Speed Diesel \\
\hline
\end{tabular}




\section{References}

[1] Andreas Paxian, Veronika Eyring, Winfried Beer, Robert Sausen, and Claire Wright, "Present- Day and Future Global Bottom-Up Ship Emission Inventories Including Polar Routes," Environmental Science and Technology 44-4 (2010):1333-1339.

[2] Apollonia Miola, Biagio Ciuffo, Emiliano Giovine, and Marleen Marr, "Regulating Air Emissions from Ships. The State of Art on Methodologies," Technologies and Policy Options. JRC Reference Reports, European Union, 2010.

[3] Apollonia Miola, V. Paccagnan, I., Mannino, A. Massarutto, A. Perujo, and M. Turvani, "External Costs of Transportation. Case study: Maritime Transport," European Commission JRC Scientific and Technical Reports (2009): 25-27.

[4] BETA Project. Benefits Table Database: Estimates of the Marginal External Costs of Air Pollution in Europe. European Commission DG Environment. Version E1.02a, 2002.

[5] CAFE Programme (The Clean Air for Europe): Towards a Thematic Strategy for Air Quality. European Commission COM(2001)245.

[6] Chengfeng Wang, James J. Corbett, and Jeremy Firestone, "Modeling Energy Use and Emissions from North American Shipping: Application of the Ship Traffic, Energy, and Environmental Model," Environmental Science \& Technology 41-9 (2007): 3226-3232.

[7] Chris Whall, David Cooper, Karen Archer, Layla Twigger, Neil Thurston, David Ockwell, Alun McIntyre, and Alistair Ritchie, “ Quantification of emissions from ships associated with ship movements between ports in the European Community”, Prepared by ENTEC UK limited for the European Commission, July 2002.

[8] Claudio Gariazzo, Vincenzo Papaleo, Armando Pelliccioni, Giuseppe Calori, Paola Radice, and Gianni Tinarelli, “Application of a Lagrangian Particle Model to Assess the Impact of Harbour, Industrial and Urban Activities on Air Quality in the Taranto Area, Italy," Atmospheric Environment 41 (2007): 6432-6444. Accessed February 20, 2011, http://dx.doi.org/10.1016/j.atmosenv.2007.06.005.

[9] Costas Giziakis, and Anastasia Christodoulou, "Environmental awareness and practice concerning maritime air emissions: the case of the Greek shipping industry,” Maritime Policy \& Management 39 (2012): 353-368.

[10] EC (European Commission). Annual European Union greenhouse gas inventory 1990-2008 and inventory report 2010. DG Climate Action European Environment Agency.

[11] EC (European Commission). European Transport Policy for 2010: Time to Decide. COM (2001)370, 2001, Brussels.

[12] ED (European Directive) 2005/33/EC of the European Parliament and of the Council of 06 July 2006 amending Directive 1999/32/EC, relating to a reduction in the sulphur content of certain liquid fuels.

[13] ENTEC. UK Ship emissions inventory.Final Report Entec (2010). Defra. 
[14] Ernestos Tzannatos, "Cost assessment of ship emission reduction methods at berth: the case of the Port of Piraeus, Greece,” Maritime Policy \& Management 37-4 (2010a): 427-445.

[15] Ernestos Tzannatos, "Ship emissions and their externalities for the port of Piraeus - Greece,” Atmospheric Environment 44 (2010b): 400-407.

[16] ESPO, ESPO-EcoPorts Port Environmental Review 2009. Executive Summary, February, 2010. http://www.ecoports.com/publications.

[17] IMO (International Maritime Organization). Amendments to the annex of the protocol of 1997 to amend the International Convention for the Prevention of Pollution from Ships, 1973, as modified by the Protocol of 1978. Relating thereto (Revised MARPOL Annex VI), adopted 10 October 2008.

[18] José María Gil Aizpuru. “Análisis de la contribución del gas natural a la reducción de emisiones atmosféricas en el sector marítimo: Aplicación práctica en el litoral de Castellón” (PhD diss., Universitat Politècnica de Catalunya, 2011).

[19] Juan José Usabiaga, “El reequilibrio modal y el Ecobono” (Master’s thesis, Universitat Politècnica de Catalunya, 2009). http://hdl.handle.net/2099.1/12758.

[20] Liesbeth Schrooten, Ina De Vlieger, Luc Int Panis, Cosimo Chiffi, and Enrico Pastori, "Emissions of Maritime Transport: A European Reference System," Science of the Total Environment 408 (2008): 318-323.

[21] Lloyd's Marine Intelligence Unit database. Accessed September 16, 2009 http://www.lloydslistintelligence.com

[22] MEPC (Marine Environment and Protection Committee), Resolution MEPC 176 (58), Annex 13, Regulation 14, October 2008.

[23] Morten Winther M. "New National Inventory for Navigation in Denmark," Atmospheric Environment 42 (2008): 4632-4655. Accessed November 15, 2009, http://dx.doi.org/10.1016/j.atmosenv.2008.01.065.

[24] Oceane Balland, Stein Ove Erikstad, and Kjetil Fagerholt, "Optimized selection of air emission controls for vessels,” Maritime Policy \& Management 39-4 (2012): 387-400.

[25] Øyvind Endresen, Eirik Sørgård, Hanna Lee Behrens, Per Olaf Brett, and Ivar S. A. Isaksen, "A historical reconstruction of ships fuel consumption and emissions", Journal of Geophysical Research 112 (2007) Accessed October 28, 2009, DOI: 10.1029/2006JD007630

[26] UNCTD (United Nations Conference on Trade and Development). Review of Maritime Transport, 2010. United Nations Publications, 2010. 